\title{
Utilization of Food Industries Wastes for The Production of Single Cell Protein by Yeasts
}

\author{
A. I. Khalil, M. S. Hassouna ${ }^{1}$ and R. H. Zaanon ${ }^{2}$
}

\begin{abstract}
To study the potential of producing single cell protein (SCP) from waste materials to decrease the protein gap and to reduce the environmental pollution, five yeast strains (Candida blankii, Candida rugosa, Pichia anomala, Kluyveromyces lactis and Rhodotorula glutinis) were used. The results of growth of the tested strains on four types of food industries wastes (cheese whey, orange peel, beet pulp and rice husk) as indicated by their protein and nucleic acids content, showed that Kluyveromyces lactis and Candida rugosa grew well on whey, while Candida blankii, Rhodotorula glutinis and Pichia anomala grew better in orange peel. The highest value of protein content was obtained with Kluyveromyces lactis on whey (6.78 g/l) followed by Candida blankii on orange peel $(6.01 \mathrm{~g} / \mathrm{l})$. On the other hand, the lowest values of protein content were found when rice husk and beet pulp were used for growth of these strains. Nucleic acids content followed the same trend of protein content and the highest value was obtained with Kluyveromyces lactis on whey $(1.05 \mathrm{~g} / \mathrm{l})$ and then Candida blankii on orange peel $(0.88 \mathrm{~g} / \mathrm{l})$, whereas rice husk and beet pulp gave the lowest values. Heat shock at 64 ${ }^{\circ} \mathrm{C}$ for $20 \mathrm{~min}$ caused a reduction in nucleic acid contents ranged from 65.2 to $88.8 \%$, whereas the reduction by ribonuclease (RNase) enzyme reached over $99.0 \%$. It is concluded that SCP could be produced from some food industries wastes providing the appropriate strain of yeast is used. Nucleic acids content can be reduced to the required limit.
\end{abstract}

\section{INTRODUCTION}

Homeless children were defined as children less The alarming rate of population growth has increased the demand for food production in developed countries in order to decrease the gap between. This has led to an increase in the number of hungry and chronically malnourished people (Perera et al., 1995; Anupama and Ravindra, 2000). It was reported earlier that the protein demands for direct human consumption and animal feeding would inevitably increase (Hours et al., 1985). Most of the developing countries have been facing malnutrition problem. The deficiency of protein in human food and animal feed is well recognized due to the rapid growth of population (Khan et al., 1992). The global scarcity of protein-rich foods lead to search for cheep alternative protein sources. Hence, the focus has shifted in recent years to exploit microbes as food sources for fortification of the food supply or for consumption as single cell protein (SCP) (Anupama and Ravindra, 2000).

Many of the developing countries where major nutritional problems exist produce an excess of materials rich in carbohydrates that can be utilized in fermentation processes to produce microbial protein, which in turn can be used to upgrade both human and animal feeds (Adoki, 2002). Different wastes have been used by various researchers to produce SCP, for example, cheese whey (Sandhu and Warriach, 1983; Willets and Uglade, 1987; Ghaly and Singh, 1989; Carlotti et al., 1991; Abdel- Rahman and Abo- Ahmed, 1992; Murad et al., 1992; Mansour et al., 1993; Ghaly and Ben Hassan, 1995; Gonzalez-Siso, 1996; Mawson, 1999; Ghaly and Kamal, 2004), corn residues (Abo- Hamed, 1993; Pece et al., 1994), wheat straw (Abo- Hamed, 1994), rice residues (El-Masry, 1983; Khaled et al., 1985; Khan et al., 1992; Kwon and Chung, 1995), sugarcane bagasse (El- Sayed et al., 1994; Nigam, 2000), beet pulp (Ghanem et al., 1991; Ghanem, 1992), fruit residues (Vaccarino et al., 1989; El-Refai et al., 1990; Adoki, 2002; De Gregorio et al., 2002; Tripodo et al., 2004), prawn-shell waste (Rhishipal and Philip, 1998), salad oil manufacturing wastewater (Zheng et al., 2005), Jerusalem artichoke extract (Gao et al., 2007).

SCP produced from microorganisms is characterized by its high nucleic acid content (Litchfield, 1989). Intake of a diet high in nucleic acid content leads to the production of uric acid from nucleic acid degradation (Anupama and Ravindra, 2000). Human consumption greater than $2.0 \mathrm{~g}$ nucleic acid equivalent per day may lead to kidney stone formation or gout (Calloway, 1974). It is recommended that nucleic acids should be reduced for the product to be safe (Anupama and Ravindra, 2000). The nucleic acid level can be reduced by several means. These include activation of endogenous RNAase by brief heat treatment up to $60-70{ }^{\circ} \mathrm{C}$ for $20 \mathrm{~min}$, alkaline hydrolysis of nucleic acids, modifications of cultural conditions with respect to nitrogen, carbon, phosphorous and zinc content or chemical extraction and removal of nucleic acids (Anupama and Ravindra, 2000). Several methods have

\footnotetext{
${ }^{1}$ Department of Environmental Studies, Institute of Graduate Studies and Research, University of Alexandria, Alexandria, Egypt.

${ }^{2}$ Department of Bioscience and Technology, Institute of Graduate Studies and Research, University of Alexandria, Alexandria, Egypt. Received December16, 2008, Accepted December 31, 2008
} 
been reported in the literature for this purpose such as a heat shock treatment to activate the endogenous nucleases (Abu- Ruwaida et al., 1988; Kurbanoglu and Algur, 1996), the use of pancreatic ribonuclease (Martinez et al. 1990), a heat shock followed by a RNase treatment (Kunhi and Rao, 1995), lyophilization (Kossaczka et al., 1990), alkaline treatment with $\mathrm{NH}_{4} \mathrm{OH}$ at $65{ }^{\circ} \mathrm{C}$ (Alvarez and Enriquez, 1988) and use of ion exchange (Lewis et al., 1982).

Therefore, the aim of this study was to investigate the possibility of using different waste materials for SCP production using different yeast strains and to reduce its nucleic acids content, by using physical and chemical methods.

\section{MATERIALS AND METHODS}

\section{Yeast strains:}

The yeast strains used in the present study were Candida blankii (NRRL Y-17068), Candida rugosa (NRRL Y-95), Pichia (Hansenula) anomala (NRRL Y366), Kluyveromyces lactis (NRRL Y-8279) and Rhodotorula glutinis (synonymous $R$. gracilis) (NRRL Y-1091). They were obtained from National Center for Agricultural Utilization Research (NCAUR), United States Department of Agriculture (USDA), Illinois, United States. These strains were grown on malt yeast extract agar (MYEA) slant at $28 \pm 2{ }^{\circ} \mathrm{C}$ for 3 days and then kept at $4{ }^{\circ} \mathrm{C}$ and recultured bimonthly.

\section{Food industries:}

The food industries wastes used as substrates for SCP production in the present study were orange peel (from domestic solid waste), beet pulp (from the Sugar Manufacturing Co. at El-Hamoul, Kafr El-Sheikh, Egypt), rice husk (from Kafr El-Sheikh Rice Mill Co., Egypt) and cheese whey (from the Pilot Dairy Factory, Faculty of Agriculture, University of Alexandria, Egypt).

\section{Ribonuclease enzyme:}

Ribonuclease A enzyme (RNase A) (EC number: 3.1.27.5) was obtained from Sigma-Aldrich, USA.

\section{Pretreatment of organic wastes:}

Orange peel and beet pulp were air-dried for 2-3 days, and then oven dried at $60-70{ }^{\circ} \mathrm{C}$ for $24 \mathrm{~h}$. They were ground by a hammer mill and stored in dry and tight containers until use. Whey and rice husk were used without pretreatment.

\section{Preparation of yeast suspension:}

Yeast suspension was prepared by adding $10 \mathrm{ml}$ sterilized distilled water to each strain slant, vortexed and then poured to another sterilized tube $(10 \mathrm{ml})$.

\section{Culture conditions:}

The basal mineral salts medium used as a growth medium according to the National Center for Agricultural Utilization Research (NCAUR) was contained (g/l): $(\mathrm{NH} 4)_{2} \quad \mathrm{SO}_{4}, \quad 2.64 ; \quad \mathrm{KH}_{2} \mathrm{PO}_{4}, \quad 2.38$; $\mathrm{K}_{2} \mathrm{HPO}_{4} .3 \mathrm{H}_{2} \mathrm{O}, 5.65 ; \mathrm{MgSO}_{4} \cdot 7 \mathrm{H}_{2} \mathrm{O}, 1.0$ and $1.0 \mathrm{ml}$ of trace elements solution, which contained $(\mathrm{g} / \mathrm{l}): \mathrm{CuSO}_{4}$. $5 \mathrm{H}_{2} \mathrm{O}, 0.3 ; \mathrm{MnSO}_{4} \cdot \mathrm{H}_{2} \mathrm{O}, 0.8 ; \mathrm{Na}_{2} \mathrm{MoO}_{4} .2 \mathrm{H}_{2} \mathrm{O}, 0.4$; $\mathrm{ZnSO}_{4} \cdot 7 \mathrm{H}_{2} \mathrm{O}, 0.3$ and $\mathrm{FeClF}_{3} \cdot 6 \mathrm{H}_{2} \mathrm{O}, 4.0$. The initial $\mathrm{pH}$ was adjusted to 7.2. Cultures were conducted in $250 \mathrm{ml}$ conical flasks containing $100 \mathrm{ml}$ mineral medium and $10.0 \%(\mathrm{v} / \mathrm{v}$ or w/v) waste. The flasks were sterilized at $120{ }^{\circ} \mathrm{C}$ for $20 \mathrm{~min}$, then inoculated with $1 \mathrm{ml}$ yeast suspension and incubated at $28 \pm 2{ }^{\circ} \mathrm{C}$ in a shaking incubator at $150 \mathrm{rpm}$ for 5 days. Samples $(10 \mathrm{ml})$ were taken carefully everyday for determination of protein and nucleic acids contents.

\section{Determination of protein content:}

Protein content was determined by two methods:

- Spectrophotometric method:

After settlement of particles in the sample, the upper portion was homogenized in a mortar with sand, prewashed with hydrochloric acid and distilled water, and then centrifuged at $3000 \mathrm{rpm}$ for $20 \mathrm{~min}$. The protein content was determined in the supernatant at $280 \mathrm{~nm}$ according to the method of Brown (1991), using a Pharmacia spectrophotometer, model Ultrospec 3000. Bovine serum albumin was used as a standard.

\section{- Kjeldahl method:}

The total nitrogen content was determined by the Kjeldahl method as described by WHO (1978). The crude protein values were obtained by multiplying the total nitrogen content by 6.25 .

\section{Determination of nucleic acids content:}

Samples were prepared as mentioned in protein determination. Nucleic acids content was measured at 260 and $280 \mathrm{~nm}$ according to the method of Brown (1991), using a Pharmacia spectrophotometer, model Ultrospec 3000 programmed for nucleic acid measurements.

\section{Reduction of nucleic acids:}

The decrease of nucleic acids was carried out by heat shock and ribonuclease (RNase) enzyme. Cultures were grown in $250 \mathrm{ml}$ conical flasks containing $100 \mathrm{ml}$ mineral medium and $1.0 \%(\mathrm{v} / \mathrm{v})$ of each sugar solution which was found to be suitable for the growth of each strain. The sugars used were glucose for Candida blankii; lactose for Candida rugosa and Kluyveromyces lactis and sucrose for Rhodotorula glutinis and Pichia (Hansenula) anomala. After sterilization, the flasks were inoculated with $1 \mathrm{ml}$ yeast suspension and incubated at $28 \pm 2{ }^{\circ} \mathrm{C}$ in a shaking incubator at $150 \mathrm{rpm}$ for 5 days. In 
case of heat shock method, samples were taken and heated in water bath at $64{ }^{\circ} \mathrm{C}$ for $20 \mathrm{~min}$, Maul et al. 1970, then nucleic acid content was measured after 30 min. On the other hand, in case of RNase enzyme method, samples were homogenized using pre-washed sand then cell growth was removed by centrifugation at $3000 \mathrm{rpm}$. The supernatants were treated with RNase-A solution at a final concentration of $10 \mathrm{mg} / \mathrm{ml}$ and then incubated in a water bath for $24 \mathrm{~h}$ at $37^{\circ} \mathrm{C}$. Nucleic acid contents were measured by spectrophotometric method at $0,3,6,9,12$ and $24 \mathrm{~h}$ intervals.

\section{Production of SCP}

\section{RESULTS AND DISCUSSION}

Organic wastes used for SCP production were cheese whey, orange peel, beet pulp and rice husk. The yeast strains used were Candida blankii (NRRL Y17068), Candida rugosa (NRRL Y-95), Pichia (Hansenula) anomala (NRRL Y-366), Kluyveromyces lactis (NRRL Y-8279) and Rhodotorula glutinis (synonymous $R$. gracilis) (NRRL Y-1091).

Growth of different strains on different wastes as indicated by protein and nucleic acids contents showed different patterns. As shown in Figure 1, whey and orange peel resulted in better growth of all strains than rice husk and beet pulp. Whey gave the highest protein content in case of Kluyveromyces lactis and Candida rugosa, while orange peel gave the highest protein content in case of Candida blankii, Rhodotorula glutinis and Pichia anomala. However, the protein content largely differed from one strain to the other. Kluyveromyces lactis gave the highest protein content on whey and even that Candida rugosa grew best on whey but the yield was almost half. The same trend was found for orange peel; Candida blankii gave the highest level followed by Rhodotorula glutinis yielding about half and then Pichia anomala, which again was less than half of the former. The results indicate that after 5 days incubation, $6.78 \mathrm{~g}$ protein/ liter produced using Kluyveromyces lactis grown on whey and $6.01 \mathrm{~g}$ protein/ liter produced by using Candida blankii grown on orange peel. It is noticed that the highest protein yield obtained when Kluyveromyces lactis was grown on whey. The yeast utilized lactose readily (whey contained $4.9 \%$ lactose). Despite that Candida rugosa utilized lactose (data not shown) but its growth on whey was not comparable with Kluyveromyces lactis. It was reported that Kluyveromyces fragilis can utilize lactose of whey because it has a unique enzyme namely lactose enzyme (Ghaly and Ben Hassan, 1993). On the other hand, Candida blankii grew better on orange peel, and this is could be attributed to the total sugar content $(7.6 \%)$ and sucrose content $(2.0 \%)$ of the orange peel. The results indicated that the lowest values of protein content were found when rice husk and beet pulp were used for growth (Figure 1). Beet pulp is composed mainly of cellulose, hemicellulose and pectin (Spagnuolo et al., 1997). It has been shown in earlier work that it can be used for SCP production by Trichoderma reesei (Ghanem et al., 1991) or by mixed culture of the former fungus and Kluyveromyces marxianus (Ghanem, 1992). Rice husk contains large amounts of lignin and fibers (Hsu and Luh, 1980) and therefore it proved to be hard to degrade and unsuitable for SCP production under the studied conditions.

Comparable results were obtained from the protein content determined by the Kjeldahl method (Figure 2). The percentage of protein in the growth media followed the same trend. The highest value was obtained for Candida blankii grown on orange peel $(0.88 \mathrm{~g} / \mathrm{l})$ followed by Kluyveromyces lactis grown on whey $(0.72 \mathrm{~g} / \mathrm{l})$. These results indicate the good potential of these strains for SCP production.

Nucleic acids content provided another evidence for the growth of the tested yeasts on different waste materials. Results of nucleic acid contents are presented in Figure 3. It is evident that nucleic acid contents were highest in case of Kluyveromyces lactis grown on whey $(1.05 \mathrm{~g} / \mathrm{l})$ followed by Candida blankii grown on orange peel $(0.88 \mathrm{~g} / \mathrm{l})$ after 5 days incubation then marginally followed by other strains. Again, rice husk and beet pulp gave the lowest values.

\section{Reduction of nucleic acids levels in yeast cells:}

In this study, two methods (heat shock and RNase) were tried for reducing the levels of nucleic acids in the fermentation broth. The effect of heat shock treatment on nucleic acids concentration and reduction is presented in Figure 4A. The heat shock treatment at $64{ }^{\circ} \mathrm{C}$ for $20 \mathrm{~min}$ followed by $30 \mathrm{~min}$ incubation caused a decrease in nucleic acids ranged from 65.2 to $88.8 \%$ (as \% of control). The reduction in nucleic acid content was 65.2 , 71.6, 74.0, 83.0 and $88.8 \%$ in case of Pichia anomala, Candida rugosa, Candida blankii, Kluyveromyces lactis and Rhodotorula glutinis, respectively. It is evident that the growth product of Rhodotorula glutinis was the most affected in nucleic acid reduction followed by Kluyveromyces lactis then the other strains. It was reported (Kurbanoglu and Algur, 1996) that one-step heat shock was carried out at $90{ }^{\circ} \mathrm{C}$ for $2 \mathrm{~h}$ and the highest nucleic acid reductions achieved for Saccharomyces cerevisiae, Candida utilis, Fusarium moniliforme and Bacillus subtilis were 95.2, 89.6, 95.5 and $75.3 \%$, respectively. On the other hand, three step heat shock was carried out at $68{ }^{\circ} \mathrm{C}$ for $3 \mathrm{~s}, 45^{\circ} \mathrm{C}$ for $2 \mathrm{~h}$ and $55{ }^{\circ} \mathrm{C}$ for $1 \mathrm{~h}$ and the maximum nucleic acid reductions obtained were $95.8,86.4,91.0$ and $78.5 \%$ for these species, respectively. It was also reported that a heat shock treatment at $65^{\circ} \mathrm{C}$ for $5-10$ min followed by 


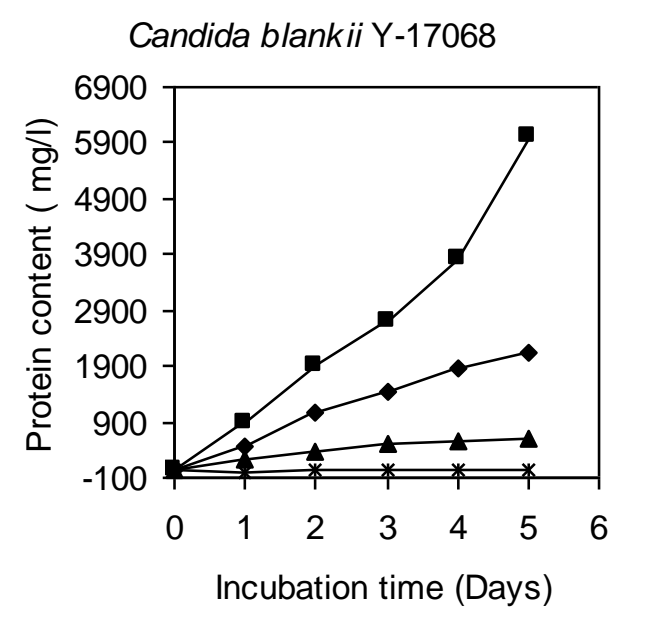

Kluyveromyces lactis Y-8279

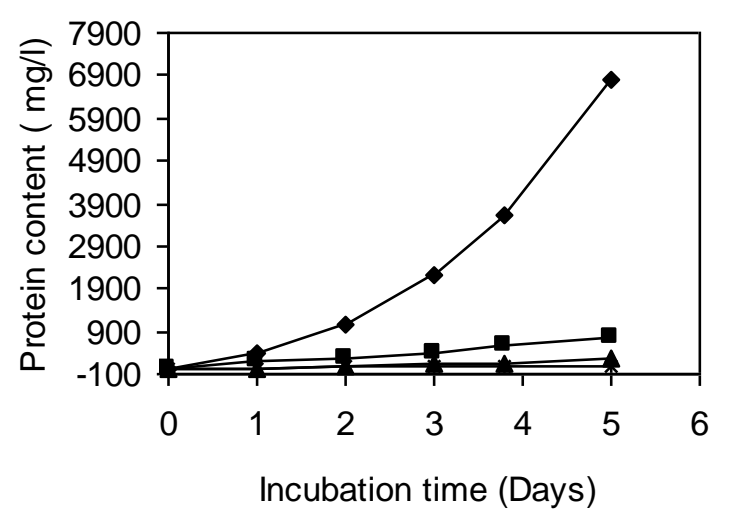

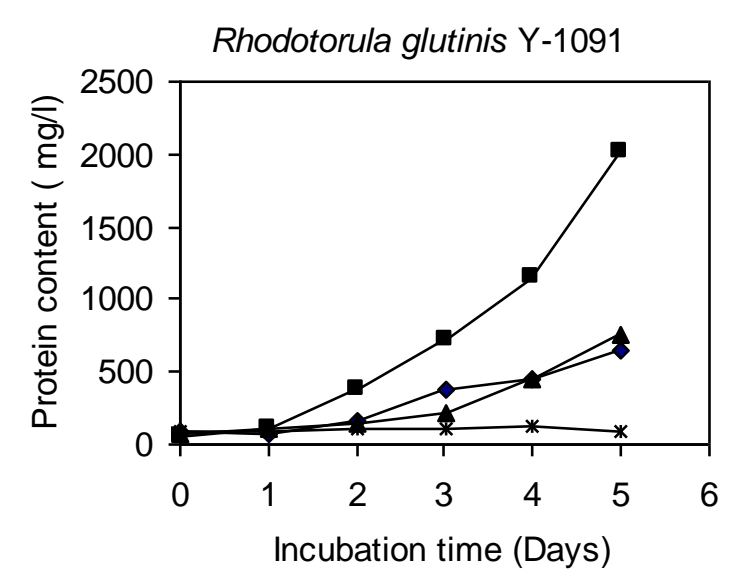

Pichia anomala Y-366

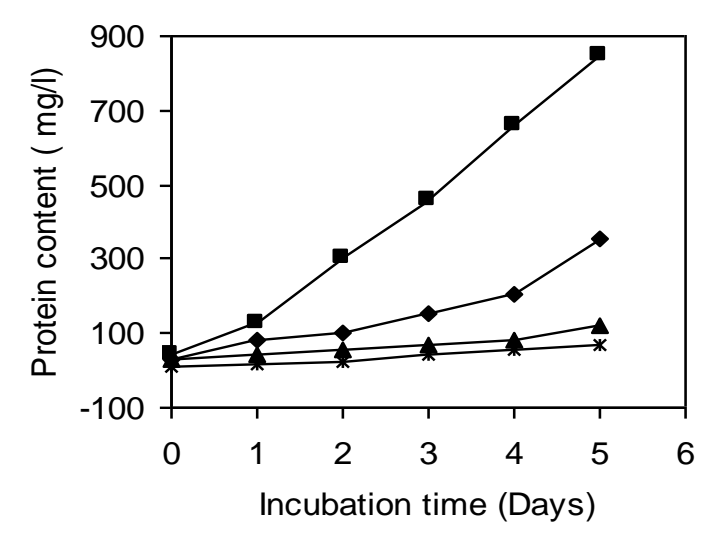

Candida rugosa Y-95

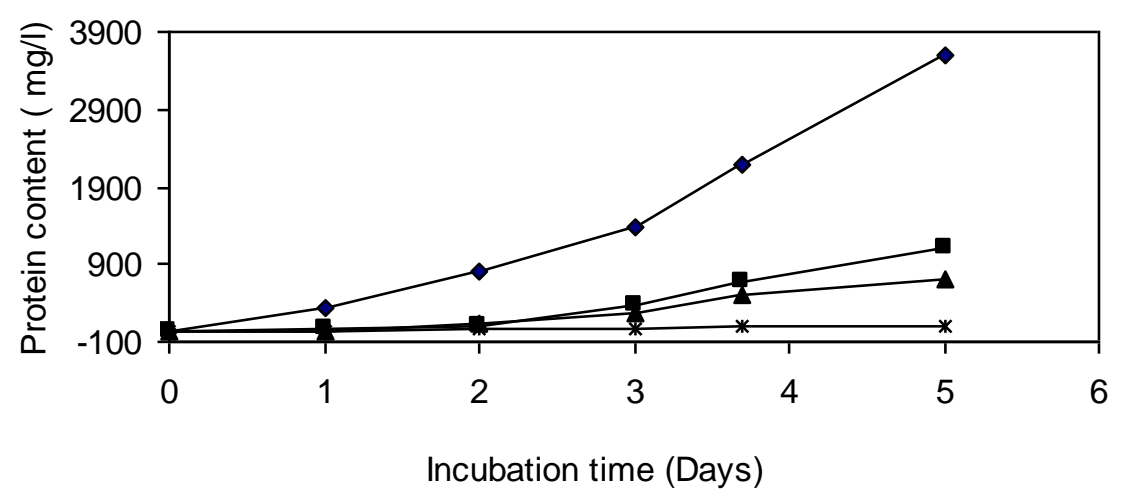

$\multimap$ Whey $\rightarrow$-Orange peel $\multimap$ Beet pulp $\rightarrow$ * Rice husk

Figure 1. Protein content in media containing different wastes inoculated with yeasts and incubated at $28 \pm 2^{\circ} \mathrm{C}$. (Measured by absorbance at $280 \mathrm{~nm}$ ) 
Candida blankii Y-17068

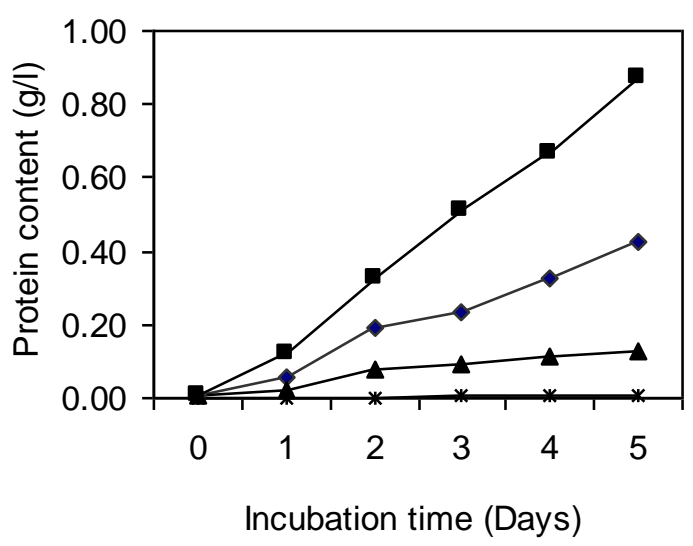

Kluyveromyces lactis Y-8279

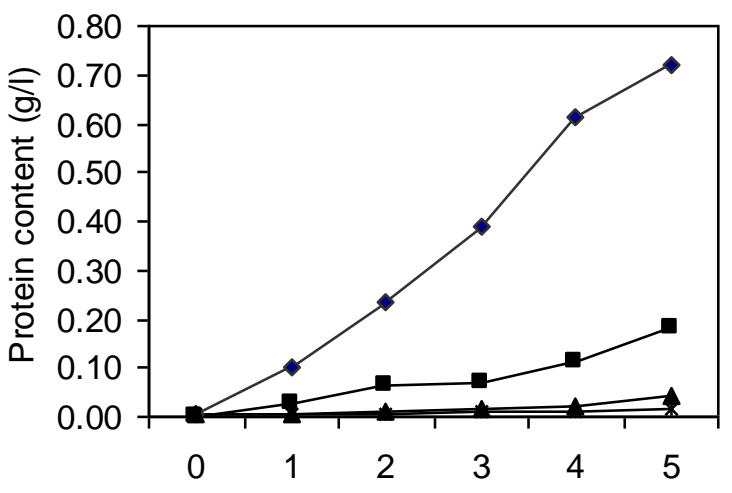

Incubation time (Days)
Rhodotorula glutinis Y-1091

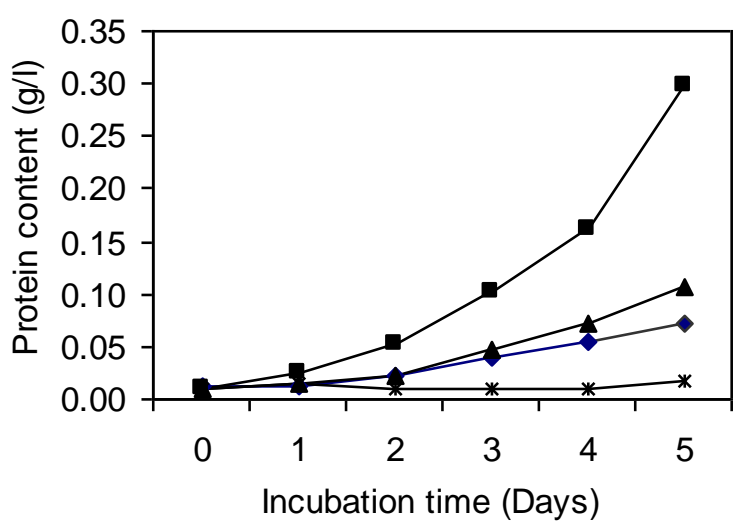

Pichia anomala Y-366

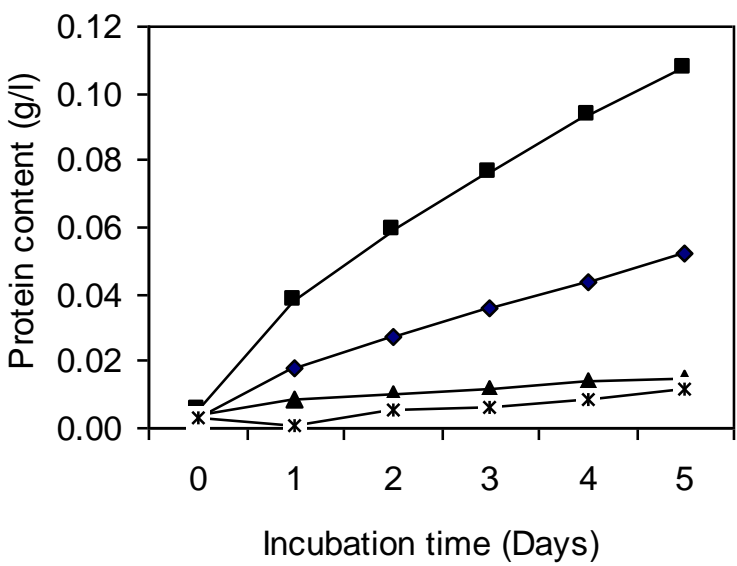

Candida rugosa Y-95

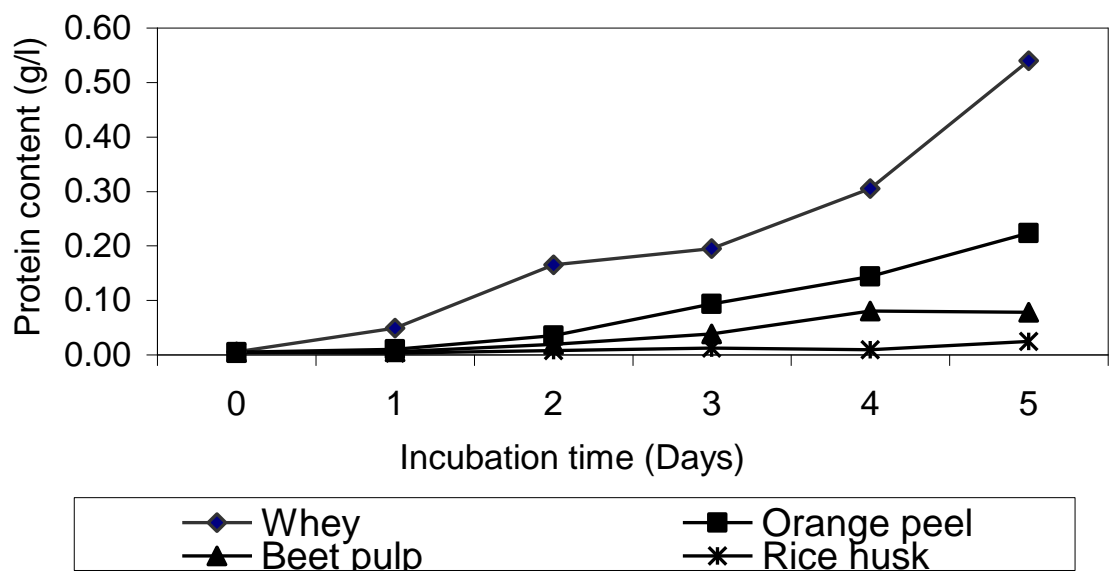

Figure 2. Protein content in media containing different wastes inoculated with yeasts and incubated at $28 \pm 2^{\circ} \mathrm{C}$. (Measured by Kjeldahl method) 
Candida blankii Y-17068

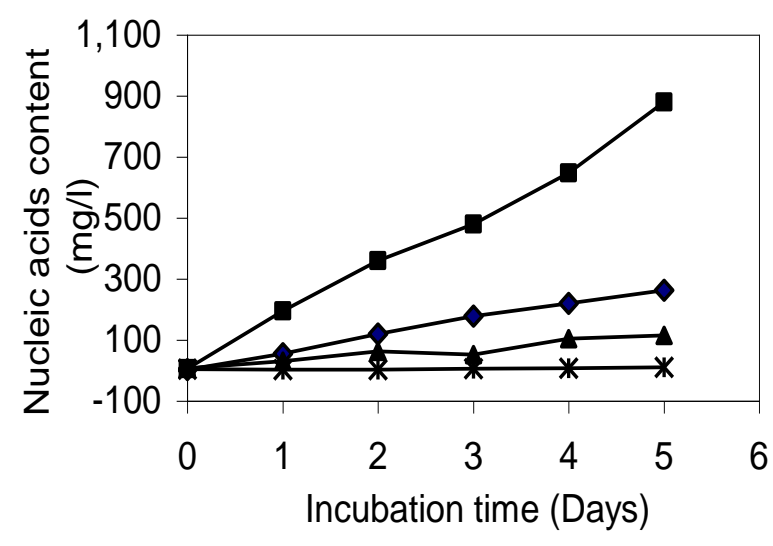

Kluyveromyces lactis Y-8279

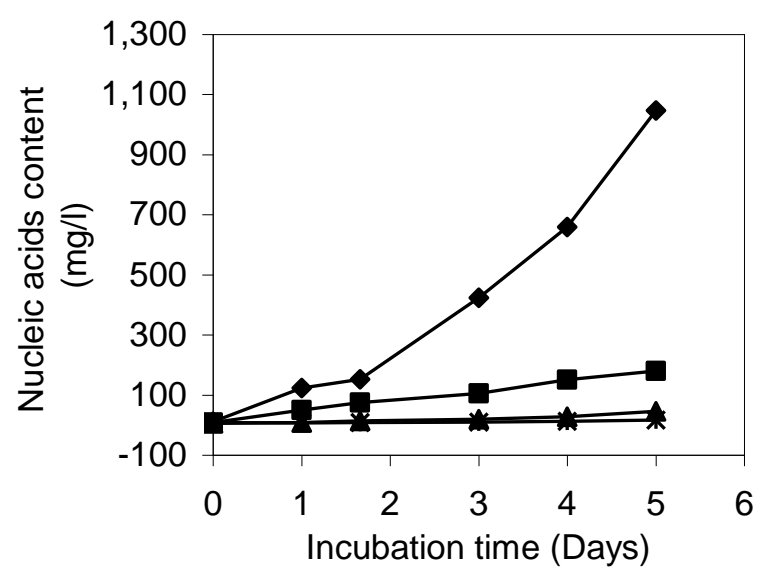

Rhodotorula glutinis Y-1091

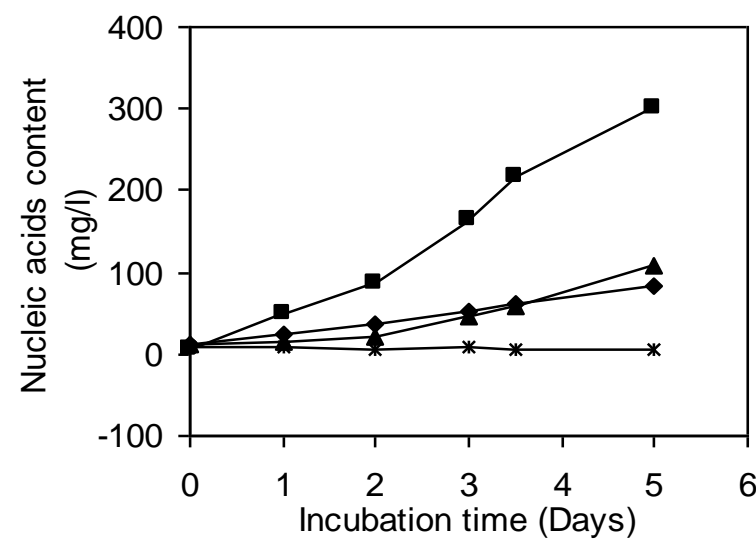

Pichia anomala Y-366

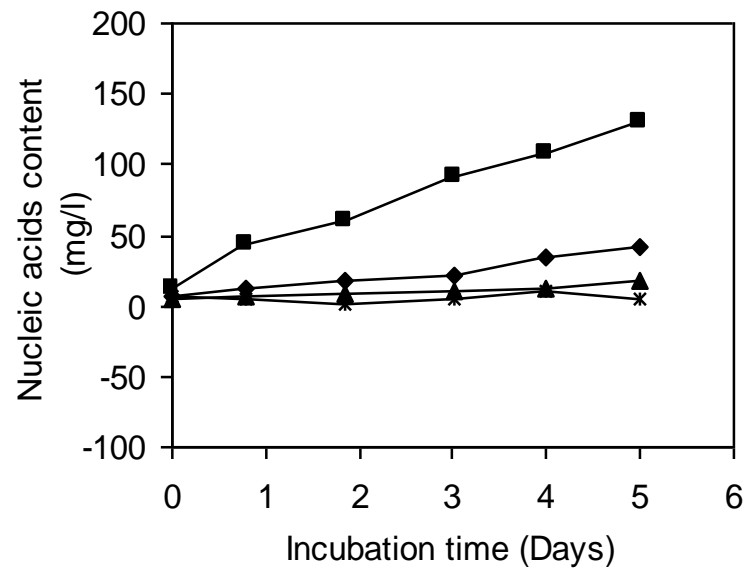

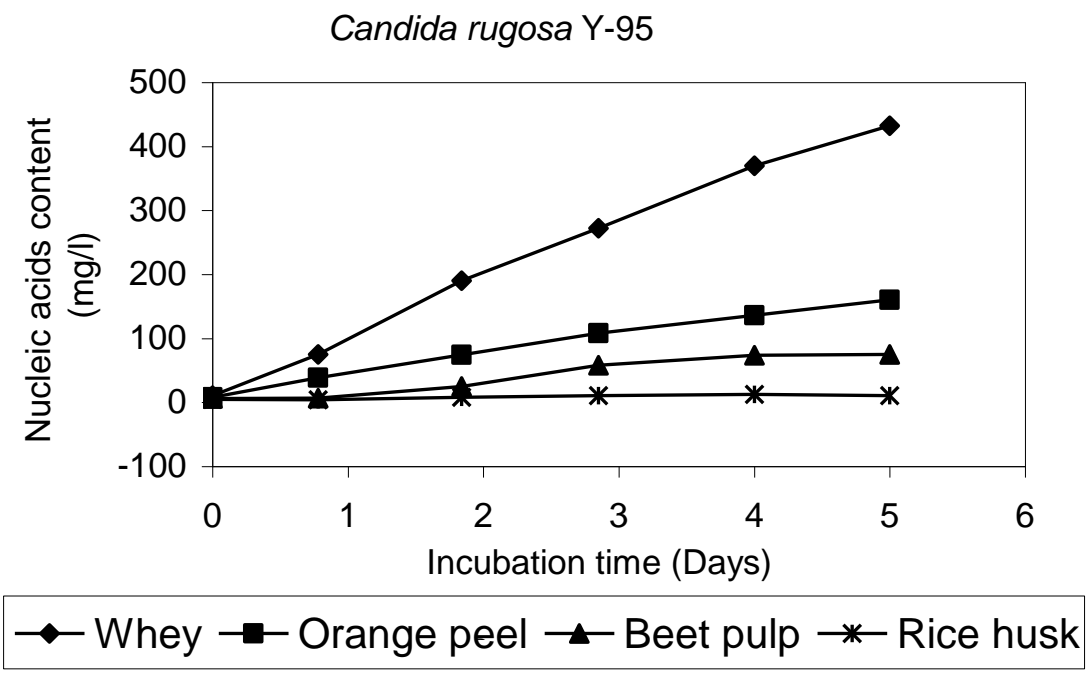

Figure 3. Nucleic acids content in media containing different wastes inoculated with yeasts and incubated at $28 \pm 2^{\circ} \mathrm{C}$ 
A

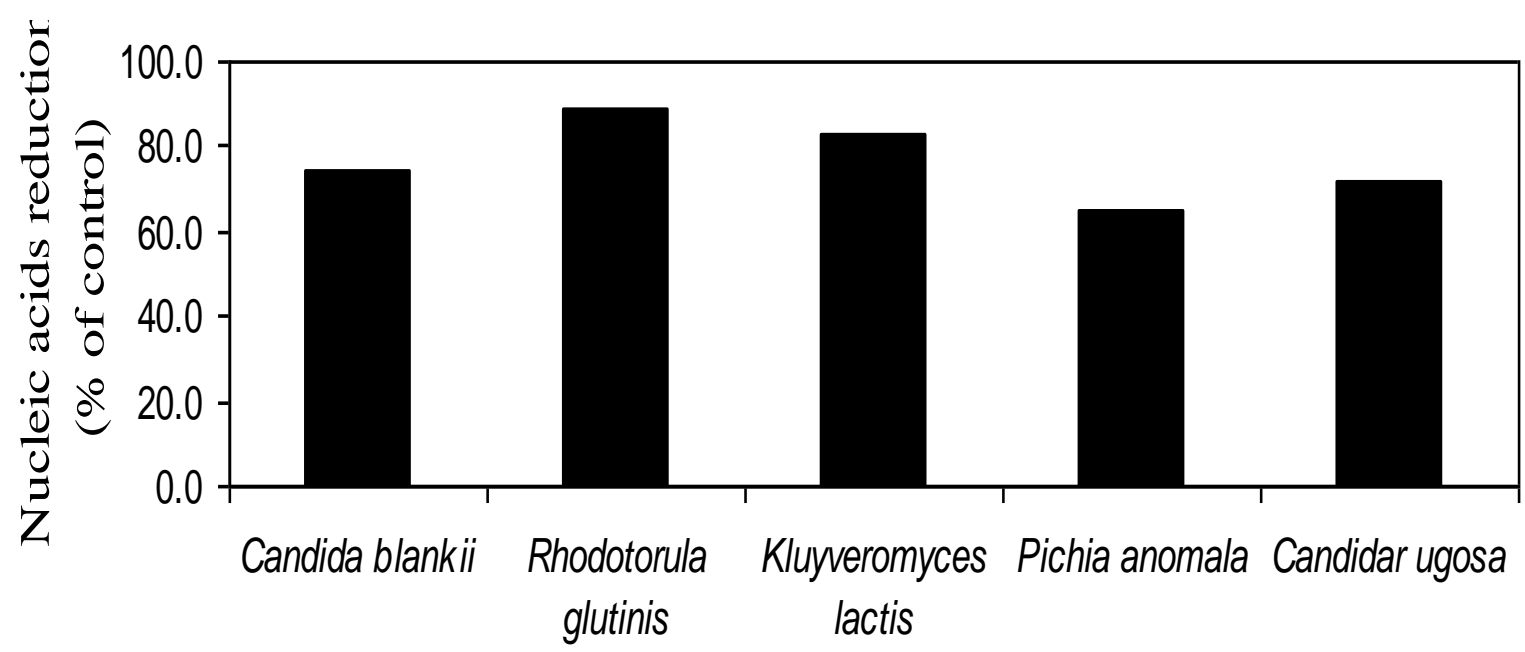

B

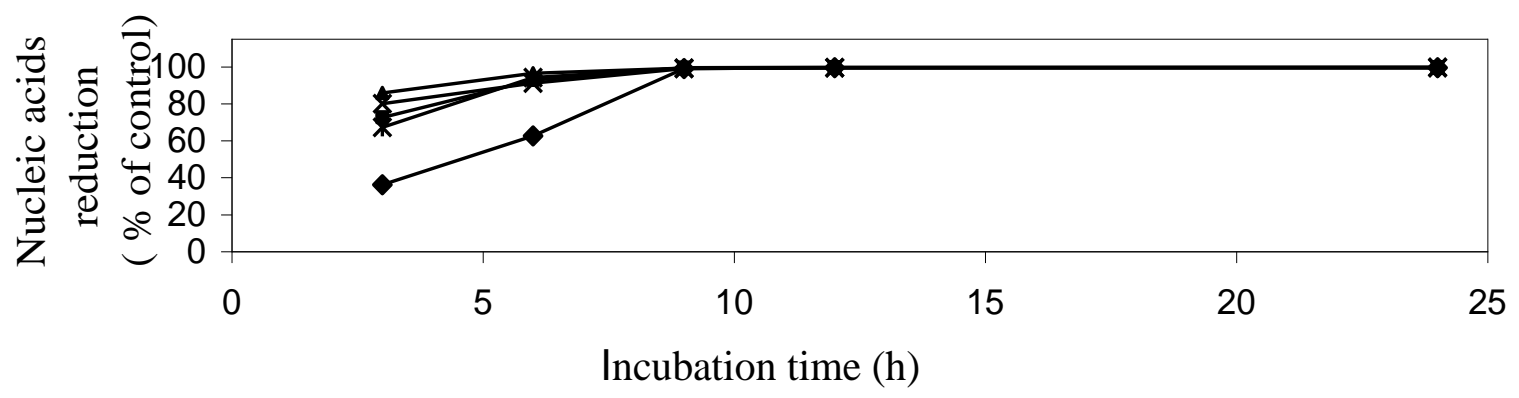

$\begin{array}{ll}\rightarrow-\text { Candida blankii } & \rightarrow-\text { Rhodotorula glutinis } \rightarrow \text { Kluyveromyces lactis } \\ \rightarrow \text { Pichia anomala } & * \text { Candidar ugosa }\end{array}$

\section{Figure 4. Effect of heat shock (A) and RNase (B) on nucleic acids reduction}

incubation at $55{ }^{\circ} \mathrm{C}$ for $2 \mathrm{~h}$ resulted in 81.0- $85.0 \%$ reduction in nucleic acid content (Abu-Ruwaida et al., 1988).

The RNase treatment was more efficient and it substantially decreased nucleic acids to less than $1.0 \%$ for all strains, but the process needed longer time. The effect of the enzyme was more pronounced within the first $9 \mathrm{~h}$ (Figure 4B). Two derivatives of pancreatic RNase and an endonuclease of Staphylococcus aureus, immobilized on corn cobs, have been used to reduce the percentage of nucleic acids in SCP concentrates of yeasts, from $5.0-15.0 \%$ to $0.5 \%$ with a protein loss of only $6.0 \%$ after treatment (Martinez et al., 1990). An immobilized pancreatic RNase was also investigated for the degradation of yeast ribonucleic acid. The rapid reaction rates obtainable at relatively low temperatures offer a potential alternative method of purifying yeast SCP with minimal loss of derived protein (Dale and White, 1979). Generally, the results of the present study proved that the use of either heat shock or RNase treatment reduced the nucleic acids to acceptable limits.

From the results obtained in this study, it can be concluded that the microbial protein can be produced from different waste materials providing that the right organism be chosen. Protein produced by this way can be used as a cheep food additive to meat products to make them more available to wider population. SCP production could indeed narrow the protein gap in diet. Alternatively, it can be used for animal feeding; this would have two advantages, one is providing a protein source instead of using fish meal and alike, and second is saving agricultural land that is currently used for animal fodder production 
and thus diverts the land for the production of some strategies crops for human consumption. An additional benefit arises, as the protein produced via microbial way would provide a good source of protein produced from waste and would alleviate the burden of imports and eventually improves the national economy.

\section{REFERENCES}

Abdel-Rahman, T.M and Abo-Ahmed, N.A.A. (1992). Whey utilization by Saccharomyces cerevisiae for production of biomass protein. Egyptian Journal of Physiological Science 16, 27-36.

Abo-Hamed, N.A.A. (1993). Microbial utilization of some agricultural and agri-industrial waste products for the production of single cell protein (SCP). Qatar University Science Journal 13(2), 226-231.

Abo- Hamed, N.A.A. (1994). Bioconversion of wheat straw by yeasts into single-cell protein. Egyptian Journal of Microbiology 28(1), 1-9.

Abu-Ruwaida, A.S., Banat, M.I. and Hamdan, Y.I. (1988). Reduction of nucleic acid content in cell biomass of methanol utilizing mixed bacterial culture by heat treatment. Biotechnology Letters 10, 597-602.

Adoki, A. (2002). Culture characteristics of Candida sp. in waste conversion: implications for single-cell- proteinenriched feed supplement production. Journal of Applied Sciences \& Environmental Management 6(2), 49-58.

Alvarez, R. and Enriquez, A. (1988). Nucleic acid reduction in yeast. Applied Microbiology and Biotechnology 29, 208-210.

Anupama and Ravindra, P. (2000). Value-added food: single cell protein. Biotechnology Advances 18, 459-479.

Brown, A.T. (1991). DNA Spectrophotometry. Essential Molecular Biology: A Practical Approach. $2^{\text {nd }}$ edition. Oxford University Press. UK

Calloway, D.H. (1974). The place of single cell protein in man's diet. In: Davis, P.(ed.). Single Cell Protein. New York: Academic Press, pp. 129-146.

Carlotti, A., Poncet, S., Pierre, J. and Jacob, F. (1991). Microbial interaction during the production of yeast on crude sweet whey. Journal of General and Applied Microbiology 37, 389-394.

Dale, B.E and White, D.H. (1979). Degradation of ribonucleic acids by immobolized ribonuclease. Biotechnology and Bioengineering 21(9), 1639-1648.

De Gregorio, A., Mandalari, G., Arena, N., Nucita, F., Tripodo, M.M. and Lo Curto, R.B. (2002). SCP and crude pectinase production by slurry- state fermentation of lemon pulps. Bioresource Technology 83, 89-94.

El-Masry, H.G. (1983). Utilization of Egyptian rice straw in production of cellulases and microbial protein: effect of various parameters on yields of protein and enzymes activity. Journal of the Science of Food and Agriculture 34, 725-732.
El-Refai, A. H., Ghanem, K.M. and El- Sabaeny, A.H. (1990). Single cell protein production from orange waste by Sporotrichum thermophilic cultivated under optimal conditions. Microbios 63(254), 7-16.

El-Sayed, S.A., Zaki, M.T., Ibrahim, E.M.A. and Abu- El Khar, A.W. (1994). Mixed cultures as a microbial treatment for nutritional upgrading of sugarcane bagasse. Egyptian Journal of Applied Science 9 (8), 530-540.

Gao, L., Chi, Z., Sheng, J., Ni, X. and Wang, L. (2007). Single-cell protein production from Jerusalem artichoke extract by a recently isolated marine yeast Cryptococcus aureus G7a and its nutritive analysis, Applied Microbiologyy and Biotechnology 77(4), 825-832.

Ghaly, A.E. and Ben Hassan, M.R. (1993). Dehydraogenase activity measurement in yeast fermentation. Applied Biochemistry and Biotechnology 43, 77-92.

Ghaly, A.E. and Ben Hassan, M.R. (1995). Kinetics of batch production of single cell protein from cheese whey. Applied Biochemistry and Biotechnology 50: 79-92.

Ghaly, A.E. and Kamal, M.A. (2004). Submerged yeast fermentation of acid cheese whey for protein production and pollution potential reduction. Water Research 38(3), 631-644.

Ghaly, A. E. and Singh, R.K. (1989). Pollution potential reduction of cheese whey through yeast fermentation. Applied Biochemistry and Biotechnology 22(2), 181203.

Ghanem, K.M. (1992). Single cell protein production from beet- pulp by mixed culture. Microbiologia 8(1): 39-43.

Ghanem, K.M., El- Refai, A. H. and Gazaerly, A.M. (1991). Protein enriched foodstuff from beet pulp. World Journal of Microbiology and Biotechnology 7, 365-371.

Gonzalez-Siso, M.I. (1996). The biotechnological utilization of cheese whey. Bioresource Technology 57, 1-11.

Hours, R.A., Massucco, E.A. and Ertola, R. J. (1985). Microbial biomass product from apple pomace in batch and fed-batch cultures. Applied Microbiology and Biotechnology 23 (1), 63-71.

Hsu, W.H. and Luh, B.S. (1980). Rice hull. In: Luh, B.S.(ed.). Rice Production and Utilization, AVI Publishing Company, INC. Westoprt, USA.

Khaled, G.M., Francis, R.R., Ramadan, E.M. and Easef, A.R. (1985). Amino acids content of single cell protein produced from rice husks hydrolysate medium. Annals of Agriculture Science 30, 63-73.

Khan, M.Y., Dahot, M.U. and Khan, M.Y. (1992). Single cell protein production by penicillium javanicum from pretreated rice husk. Journal of Islamic Academy of Sciences 5(1), 39-43.

Kossaczka, Z., Votjkova, A.L. and Machova, E. (1990). Autolytic reduction of the nucleic acid content in Candida utilis. Journal of Basics Microbiology 30, $337-$ 340.

Kunhi, A.A.M. and Rao, R.R.M. (1995). The utility of fungal ribonuclease for reducing the nucleic acid content of permeabilized yeast cells. Food Biotechnology 9, 13-28. 
Kurbanoglu, E.B. and Algur, O. F. (1996). The effect of methods of one and three step heat shock on the reduction of nucleic acid content of single cell protein. Turkish Journal of Biology 20, 183-190.

Kwon, O.J. and Chung, G.Y. (1995). Production of single cell protein on rice straw and their utilities. Agriculture Chemistry and Biotechnology 38, 496-501.

Lewis, P.N., Lawford, G.H., Kligerman, A. and Lawford, R.G. (1982). A novel method for reducing RNA content of single cell protein isolates. Biotechnology Letters 4, 441-446.

Litchfield, H.J. (1989). Single cell protein, In: Marx, L.J. (ed.). A Revolution in Biotechnology. Cambridge University Press, UK, pp. 71-81.

Mansour, M.H., Ghaly, A. E., Ben Hassan, M.R. and Nassar, A.M. (1993). Modeling patch production of single cell protein from cheese whey: 1. Kluyverimyces fragilis growth. Applied Biochemistry and Biotechnology 43, 114.

Martinez, M.C., Sanchez-Montero, J.M., Sinisterra, J. V. and Ballesteros, A. (1990). New insolubilized derivatives of ribonuclease and endonuclease for elimination of nucleic acids in single cell protein concentrates. Biotechnology and Applied Biochemistry 12(6), 643652.

Maul, S.B., Sinskey, J.A. and Tannenbaum, S. R. (1970). A new process for reducing the nucleic acid content of yeast. Nature 22, 181-182.

Mawson, J.A. (1999). Bioconversions for whey utilization as waste abatement. Bioresource Technology 47, 195-203.

Murad, H.A., Abdel-Ghani, S. and El-Shenawy, K. (1992). Bioconversions of whey permeate into Kluyverimyces lactis biomass. Egyptian Journal of Bioscience 20, 261271.

Nigam, J.N. (2000). Cultivation of Candida langeronii in sugarcane bagasse hemicellulosic hydrolyzate for the production of single cell protein. World Journal of Microbiology and Biotehnology 16, 367-372.
Pece, N., Perotti, N. and Molina, O. (1994). Bacterial protein production from corn cob pretreated with $\mathrm{NaOH}$ at room temperature. World Journal of Microbiology and Biotechnology 10(5), 593-594.

Perera, W.M., Carter, C. G. and Houlihan, D. F. (1995). Feed consumption, growth and growth efficiency of rainbow trout (Onchorhyncus mykiss (Walbaum)) fed on diet containing bacterial single cell protein. British Journal of Nutrition 73, 591-603.

Rhishipal, R.and Philip, R. (1998). Selection of marine yeasts for generation of single cell protein from prawn-shell waste. Bioresource Technology 65, 255-256.

Sandhu, D.K. and Warriach, K.M. (1983). Conversion of cheese whey to single cell protein. Biotechnology and Bioengineering 25, 797-808.

Spagnuolo, M. Crecchio, C., Pizzigallo, M.D.R. and Ruggiero, P. (1997). Synergistc effects of cellulolytic and pectinolytic enzymes in degrading sugar beet pulp. Bioresource Technology 60, 215-222.

Tripodo, M. M., Lanuzza, F., Micali, G., Coppolino, R. and Nucita, F. (2004). Citrus waste recovery: a new environmentally friendly procedure to obtain animal feed. Bioresource Technology 91(2), 111-115.

Vaccarino, C., Curto, R. B., Tripodo, M.M., Patanè, R.M., Laganá, G. and Schachter, S. (1989). SCP from orange peel by fermentation with fungi. Submerged and surface fermentations. Biological Wastes 29, 279-287.

WHO. International Reference Center for Wastes Disposal. (1978). Methods of Analysis of Sewage Solid Wastes and Compost. CH-8600, Bübendorf, Switzerland.

Willets, A. and Uglade, U. (1987). The production of single cell protein from whey. Biotecnology Letters 9, 795-800.

Zheng, S., Yang, M. and Yang, Z. (2005). Biomass production of yeast isolate from salad oil manufacturing wastewater. Bioresource Technology 96(10), 1183-1187. 


\section{الملخص العربي}

\section{إنتاج البروتين وحيد الخلية من الخميرة باستخدام مخلفات الصناعات الغذائية}

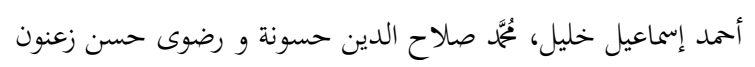

أشارت النتائج إلى أن محتوى الأحماض النووية كان لـه نفس

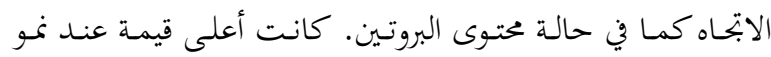
Kluyveromyces lactis ذلك عنـد نمو Candida blankii على قشـ البرتقـال (0.88 جم/لتر)، بينما أقل قيمة كانت عند استخدام سرسة الأرز وتلي

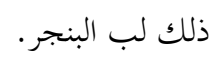

64) (Heat shock) أدى استخدام طريقة الصدمة الحرارية (H) م ملمدة 20 دقيقة) إلى النخفاض في محتوى الأحماض النووية يتراوح

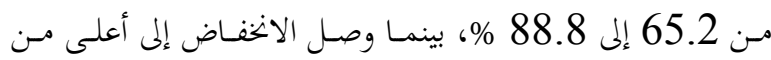
99 عند استخدام إنزيم الريبونيوكلياز (RNase).

نستتنج من النتائج المتحصل عليها إمكانية إنتاج البروتين من

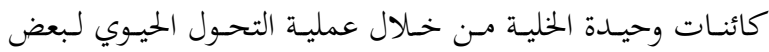
مخلفات الصناعات الغذائية وذلك في محاولة لتقليل الفجوة في نقص البروتين، علاوة على تقليل التلوث الناتج من هذه المخلفات. كما

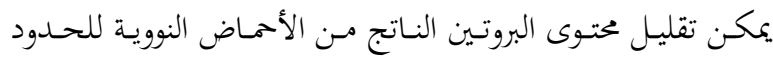

$$
\text { المقبولة. }
$$

أجريت هـذه الدراسة بهـدف إنتـاج البروتين وحيد الخليـة مـن

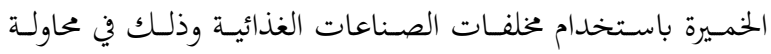
لتقليل الفجوة في نقص البروتين. لذلك تم تنمية 5 سلالات مـن (Candida blankii, Candida rugosa, Pichia الخمائر anomala, Kluyveromyces lactis and Rhodotorula glutinis)

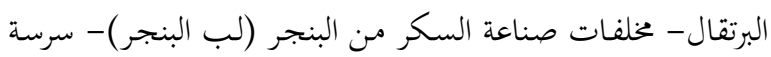

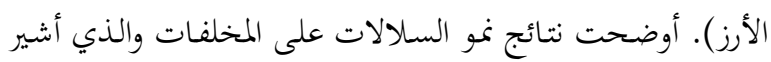

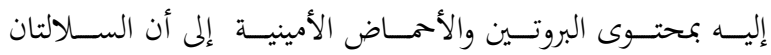
Candida rugosa و Kluyveromyces lactis Aichia و Candida blankii شـرش اللبن، بينمـا السـلالتان anomala

أشارت النتائج إلى أن أعلى قيمة للبروتين تم الحصـول عليها

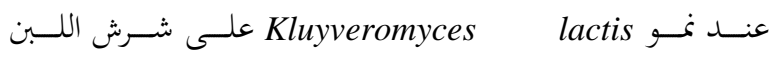

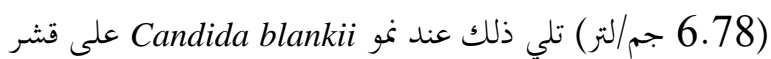
البرتقال (6.01 جـم/لتر). على الجانب الآخر، كانت أقل قيمة للبروتين عند استخدام سرسة الأرز للنمو وتلي ذلك لب البنجر. 